\title{
Dietary glycaemic index and glycaemic load in relation to body mass index, body composition and waist circumference in post pubertal adolescents from Bedfordshire
}

\author{
B. R. Davies, D. P. Bailey, S. A. Kozub and C. J. Kerr \\ Physical Activity, Nutrition and Health Research Group, Institute of Sport and Physical Activity Research, \\ Department of Sport and Exercise Science, University of Bedfordshire, Bedford, UK
}

Glycaemic index (GI) and Glycaemic load (GL) have been positively associated with body mass index (BMI) ${ }^{(1)}$ and obesity related cardiometabolic risk factors in adults ${ }^{(2)}$, but limited research exists for such relationships in adolescent populations.

The associations of GI and GL with adiposity measures were assessed in 14-19 year old, postpubertal adolescents ( $n=47)$ from Bedfordshire, U.K. Data were collected as part of ongoing research studies; the SIRENS study (study of insulin resistance factors using exercise and nutritional strategies) and the CROSSROADS study (cross sectional study: risk of adolescent disease). Dietary intake was recorded using 3 day weighed food diaries and analysed using Compeat ${ }^{\circledR}$ nutritional analysis software. Macronutrient intake, as well as GI and GL were adjusted for energy intake using the residuals method ${ }^{(3)}$. Other measures included BMI, body fat percentage $(\% \mathrm{BF})$, waist circumference (WC) and a maximal test of cardiorespiratory fitness ( $\mathrm{VO}_{2}$ peak).

\begin{tabular}{|c|c|c|c|c|c|c|c|c|}
\hline \multirow[b]{2}{*}{ Dependent } & \multicolumn{4}{|c|}{ Male $(n=24)$} & \multicolumn{4}{|c|}{ Female $(n=23)$} \\
\hline & Predictors & $\beta$ & SE & $P$ & Predictors & $\beta$ & $\mathrm{SE}$ & $P$ \\
\hline BMI & $\begin{array}{l}\mathrm{VO}_{2} \text { peak } \\
\mathrm{GI}\end{array}$ & $\begin{array}{r}-0.713 \\
0.318\end{array}$ & $\begin{array}{l}0.132 \\
0.131\end{array}$ & $\begin{array}{l}0.000 \\
0.025\end{array}$ & $\begin{array}{r}\mathrm{VO}_{2} \text { peak } \\
\text { PRO } \\
\text { Fat }\end{array}$ & $\begin{array}{l}-0.645 \\
-0.254 \\
-0.456\end{array}$ & $\begin{array}{l}0.121 \\
0.123 \\
0.123\end{array}$ & $\begin{array}{l}0.000 \\
0.050 \\
0.001\end{array}$ \\
\hline$\% \mathrm{BF}$ & $\begin{array}{l}\mathrm{VO}_{2} \text { peak } \\
\mathrm{GI}\end{array}$ & $\begin{array}{r}-0.654 \\
0.318\end{array}$ & $\begin{array}{l}0.131 \\
0.118\end{array}$ & $\begin{array}{l}0.000 \\
0.014\end{array}$ & $\begin{array}{r}\mathrm{VO}_{2} \text { peak } \\
\text { PRO } \\
\text { Fat }\end{array}$ & $\begin{array}{l}-0.696 \\
-0.322 \\
-0.289\end{array}$ & $\begin{array}{l}0.125 \\
0.126 \\
0.127\end{array}$ & $\begin{array}{l}0.000 \\
0.018 \\
0.032\end{array}$ \\
\hline WC & $\begin{array}{l}\mathrm{VO}_{2} \text { peak } \\
\mathrm{GI}\end{array}$ & $\begin{array}{r}-0.716 \\
0.281\end{array}$ & $\begin{array}{l}0.135 \\
0.125\end{array}$ & $\begin{array}{l}0.000 \\
0.050\end{array}$ & $\begin{array}{r}\mathrm{VO}_{2} \text { peak } \\
\mathrm{GL} \\
\mathrm{PRO} \\
\mathrm{Fat} \\
\mathrm{CHO}\end{array}$ & $\begin{array}{r}-0.739 \\
1.640 \\
-0.610 \\
-0.639 \\
-1.707\end{array}$ & $\begin{array}{l}0.111 \\
0.651 \\
0.162 \\
0.177 \\
0.676\end{array}$ & $\begin{array}{l}0.000 \\
0.023 \\
0.002 \\
0.002 \\
0.022\end{array}$ \\
\hline
\end{tabular}

$\beta$, standardized regression coefficients; sE, standard error of $\beta$

Backward multiple linear regression was used to analyse the contribution of dietary factors in predicting adiposity (BMI, \%BF and WC). Predictor variables entered into the model were: adjusted intakes of GI, GL, carbohydrate (CHO), protein (PRO), fat and fibre as well as cardiorespiratory fitness, ethnicity and sex. Primary analysis revealed that GI and GL were not significant predictors of any adiposity measures. However, when analysed separately according to sex, $\mathrm{VO}_{2}$ peak (negative) and GI (positive) were significant predictors of BMI $(F=18.489 ; P<0.001), \% \mathrm{BF}(F=14.509 ; P<0.001)$ and WC $(F=16.870 ; P<0.001)$ in males, explaining $60.3 \%, 70.1 \%$, and $58 \%$ of the variance, respectively. In females, GL (positive) was a significant predictor of WC, with $\mathrm{VO}_{2}$ peak, $\mathrm{PRO}, \mathrm{Fat}$ and $\mathrm{CHO}$ (negative) also contributing to the model $(F=11.528 ; P<0.001)$ which explained $74.2 \%$ of the variance between WC and the predictor variables.

In conclusion, in this sample of U.K. adolescents, increased dietary GI in males and GL in females are associated with higher values of adiposity. Increased adiposity, particularly when centrally located, is known to contribute to an increased risk of poor cardiometabolic health ${ }^{(4)}$, thus a diet lower in GI and GL may promote good health in this population.

1. Brand-Miller JC, Holt SHA, Pawlak BB, McMillan J et al. (2002) Am J Clin Nutr 76, 281-285.

2. Du H, van der A DL, van Bakel MME et al. (2008) Am J Clin Nutr 87, 665-661.

3. Willett W \& Stampfer MJ (1986) Am J Epidemiology 124, 17-27.

4. Joliffe CJ \& Janssen I (2007) J Am Coll Cardiol 49, 891-898. 